\title{
Research and Analysis on the Differences of Social Development in
}

\author{
Yunnan Province \\ $\mathrm{Gu} \mathrm{He}^{1 \star} \quad$ Fan Lin $^{2}$ \\ ${ }^{1,2}$ School of Public Management, Yunnan University of Economics and Finance, \\ Kunming, P.R.China, 650221 \\ (5615694@qq.com, 499590130@qq.com)
}

\begin{abstract}
Compiled by comprehensive development indexes of Yunnan province, the research and analysis show that regional differences are very prominent in social development. In the process of accelerating economic and social development and promoting the equalization of basic public services, the government should focus on the differences of regional development. Then specifically enhance the regional coordinated development, and strengthen the balance between economic and social development.
\end{abstract}

Keywords: Yunnan Province; Comprehensive Development Indicators; Differences of Social Development

\section{Introduction}

There're internal differences in Yunnan's economic and social development. For a comparative analysis on the differences of social development, we compiled the comprehensive development indicators for states and municipalities of Yunnan province. Target selection is mainly based on the principles of accessibility (whether the data can easily access through open channels) and representativeness (whether the data can represent regional social development). A total of eighteen indexes are included, and the target can be broadly divided into three categories: economic development indicators, social development indicators, environmental state indicators. Data primarily derived from statistics of Yunnan province 2011, the statistical bulletin of states and municipalities, and the government work report.

\begin{tabular}{|c|c|c|c|c|c|c|}
\hline $\begin{array}{c}\text { Economic } \\
\text { Development Index }\end{array}$ & $\begin{array}{c}\text { Per Capita } \\
\text { GDP } \\
\text { (yuan) }\end{array}$ & $\begin{array}{c}\text { Per Capita } \\
\text { Financial } \\
\text { Revenue } \\
\text { (yuan) }\end{array}$ & $\begin{array}{c}\text { Proportion } \\
\text { of the } \\
\text { Increased } \\
\text { Value of } \\
\text { the Tertiary } \\
\text { Industry to } \\
\text { GDP(\%) }\end{array}$ & $\begin{array}{c}\text { Urban Residents' } \\
\text { Per Capita } \\
\text { Disposable } \\
\text { Income } \\
\text { (yuan) }\end{array}$ & $\begin{array}{c}\text { Farmers Net } \\
\text { Income Per } \\
\text { Capita } \\
\text { (yuan) }\end{array}$ & $\begin{array}{c}\text { Income Ratio } \\
\text { between Urban } \\
\text { and Rural Areas } \\
\text { (rural areas is 1) }\end{array}$ \\
\hline Kunming & 38831 & 4916 & 48.4 & 21700 & 6985 & 3.11 \\
\hline Yuxi & 37913 & 3341 & 27.7 & 18527 & 6616 & 2.80 \\
\hline Qujing & 20588 & 1502 & 27.9 & 18408 & 5035 & 3.66 \\
\hline Baoshan & 12847 & 1120 & 36.5 & 16222 & 4439 & 3.65 \\
\hline Pu'er & 11795 & 1539 & 34.1 & 14877 & 4338 & 3.43 \\
\hline Lincang & 11166 & 877 & 29.6 & 14147 & 4284 & 3.30 \\
\hline Lijiang & 14279 & 2101 & 41.2 & 15812 & 4270 & 3.70 \\
\hline
\end{tabular}


Table 1 The economic development

\begin{tabular}{|c|c|c|c|c|c|c|}
\hline $\begin{array}{c}\text { Economic } \\
\text { Development Index }\end{array}$ & $\begin{array}{c}\text { Per Capita } \\
\text { GDP } \\
\text { (yuan) }\end{array}$ & $\begin{array}{c}\text { Per Capita } \\
\text { Financial } \\
\text { Revenue } \\
\text { (yuan) }\end{array}$ & $\begin{array}{c}\text { Proportion } \\
\text { of the } \\
\text { Increased } \\
\text { Value of } \\
\text { the Tertiary } \\
\text { Industry to } \\
\text { GDP(\%) }\end{array}$ & $\begin{array}{c}\text { Urban Residents' } \\
\text { Per Capita } \\
\text { Disposable } \\
\text { Income } \\
\text { (yuan) }\end{array}$ & $\begin{array}{c}\text { Farmers Net } \\
\text { Income Per } \\
\text { Capita } \\
\text { (yuan) }\end{array}$ & $\begin{array}{c}\text { Income Ratio } \\
\text { between Urban } \\
\text { and Rural Areas } \\
\text { (rural areas is 1) }\end{array}$ \\
\hline Zhaotong & 8877 & 622 & 32.4 & 14073 & 3294 & 4.27 \\
\hline Nujiang & 11968 & 1243 & 50.1 & 12117 & 2362 & 5.13 \\
\hline Xishuangbanna & 17357 & 1546 & 40.7 & 14815 & 5327 & 2.78 \\
\hline Dali & 16376 & 1324 & 36.3 & 17713 & 4733 & 3.74 \\
\hline Honghe & 17270 & 1610 & 30.0 & 16789 & 4650 & 3.61 \\
\hline Chuxiong & 17899 & 1394 & 34.4 & 17785 & 4627 & 3.84 \\
\hline Dehong & 14157 & 1554 & 38.9 & 15230 & 4096 & 3.72 \\
\hline Diqing & 23996 & 2141 & 50.7 & 17900 & 4105 & 4.36 \\
\hline Wenshan & 11364 & 777 & 38.8 & 16650 & 3864 & 4.31 \\
\hline Yunnan & 19265 & 2407 & 41.6 & 18576 & 4722 & 3.93 \\
\hline
\end{tabular}

Table 1 (Continued)

Data source: Yunnan Bureau of Statistics

\section{The Differences of Social Development in Yunnan Province}

\subsection{The Differences of Economic Development}

Table one is the main indicators of economic development in the states and municipalities of Yunnan province. From the perspective of Yunnan, compared with 2010, the economic development of Yunnan province achieved growth or optimization in 2011, especially in the indexes of per capita GDP, per capita financial revenue, the proportion of the increased value of the tertiary industry to GDP, urban residents' per capita disposable income, farmers net income per capita, the income ratio between urban and rural areas. All of the above shows that the economic development situation is relatively stable and the quality of economic development is in continuous optimization. Only in two indexes, per capita GDP and per capita financial revenue, the states and municipalities have a great difference from the comparison of economic development. The highest per capita GDP in Kunming is more than four times higher than the lowest in Zhaotong. The per capita financial revenue in Kunming is even eight times that in Zhaotong. From the income ratio of urban-rural residents, on the national level, the ratio of urban residents' per capita disposable income to farmers net income per capita is 3.13 to 1 in 2011. While Yunnan province is 3.93 to 1 , this is significantly higher than the national level. In the city of Yunnan province, except Kunming, Yuxi, and Xishuangbanna city, this ratio is also higher than the national level. Nujiang prefecture has the largest income gap between urban and rural areas, and the income of urban residents is five times that of rural residents. It thus can be seen that the economic development of Yunnan province has a large gap not only among regions, but also between urban and rural areas. In addition, it can also be found from table one that some regions with higher economic aggregate are relatively low in per capita economic indicators. For instance, Qujing's GDP that is second only to Kunming has approached 120.9 billion yuan in 2011. However, its per capita GDP ranks only fourth and per capita financial revenue ranks only ninth in the entire province. It shows that there are still quite a few problems in the quality of economic development. Generally speaking, the economic development of our province is better, but there are great internal differences in economy development level and economy development quality. It still faces great difficulties to narrow the economic development gap in different regions and urban-rural areas. 


\begin{tabular}{|c|c|c|c|c|c|c|}
\hline $\begin{array}{c}\text { Social } \\
\text { Development Index }\end{array}$ & $\begin{array}{l}\text { Urbanization } \\
\text { Rate (\%) }\end{array}$ & $\begin{array}{c}\text { Urban } \\
\text { Registered } \\
\text { Unemployme } \\
\text { nt Rate (\%) }\end{array}$ & $\begin{array}{l}\text { Secondary } \\
\text { Gross } \\
\text { Enrollment } \\
\text { Rate (\%) }\end{array}$ & $\begin{array}{c}\text { New Rural Medical } \\
\text { Cooperative Care } \\
\text { Participation Rate } \\
(\%)\end{array}$ & $\begin{array}{l}\text { Television } \\
\text { Coverage } \\
\text { (\%) }\end{array}$ & $\begin{array}{c}\text { Radio } \\
\text { Coverage } \\
(\%)\end{array}$ \\
\hline Kunming & 65.4 & 2.0 & 87.2 & 96.5 & 98.9 & 99.2 \\
\hline Yuxi & 40.0 & 3.1 & 81.8 & 95.6 & 98.8 & 98.6 \\
\hline Qujing & 37.6 & 3.0 & 86.8 & 96.3 & 96.2 & 96.3 \\
\hline Baoshan & 31.7 & 3.9 & 61.6 & 96.0 & 94.7 & 96.0 \\
\hline Pu'er & 32.3 & 4.2 & 55.2 & 95.6 & 98.1 & 96.2 \\
\hline Lincang & 32.5 & 4.0 & 54.0 & 96.8 & 96.3 & 95.5 \\
\hline Lijiang & 28.0 & 3.4 & 60.3 & 96.9 & 95.0 & 90.0 \\
\hline Zhaotong & 22.6 & 4.4 & 40.0 & 95.8 & 94.3 & 92.7 \\
\hline Nujiang & 22.7 & 4.2 & 59.8 & 97.2 & 93.5 & 88.5 \\
\hline Xishuangbanna & 40.0 & 2.2 & 54.5 & 97.8 & 99.0 & 99.0 \\
\hline Dali & 36.0 & 4.1 & 73.1 & 95.9 & 98.8 & 96.0 \\
\hline Honghe & 37.0 & 3.6 & 56.1 & 96.1 & 96.7 & 96.1 \\
\hline Chuxiong & 33.8 & 3.3 & 71.2 & 96.5 & 97.5 & 97.2 \\
\hline Dehong & 35.0 & 4.0 & 48.8 & 98.4 & 94.0 & 93.7 \\
\hline Diqing & 25.3 & 3.9 & 53.1 & 97.4 & 96.4 & 96.4 \\
\hline Wenshan & 30.6 & 3.7 & 52.7 & 95.5 & 95.4 & 94.3 \\
\hline Yunnan & 36.8 & 4.1 & 70.0 & 96.0 & 96.7 & 95.7 \\
\hline
\end{tabular}

Table 2 The social development

Data source: Yunnan Bureau of Statistics

\subsection{The Differences of Social Development}

Table two is the main indicators of social development in the states and municipalities of Yunnan province. It can be seen that there is no large gap in the indicators of the new rural medical cooperative care participation rate, radio and television comprehensive population coverage. But there's obvious gap in the indicators of urbanization rate, the registered urban unemployment rate, and secondary gross enrollment rate. Judging from the urbanization rate index of 2011, the urbanization rate of Yunnan province has approached 36.8\%. Only at the national average level ten years ago, this rate is far below the national average level of $51.27 \%$ in 2011. Judging from the states and municipalities, only the urbanization rate of Kunming is more than 50\%. The urbanization level of Yuxi and Xishuangbanna is over $40 \%$. These cities has entered rapid development phase of urbanization. There are 9 states and municipalities where the urbanization level is around $30 \%$, and the level of urbanization is basically at the level of the middle class. Their urbanization level is in the transition period which refers to the period from the initial development to the rapid development phase. In the next twenty years, the urbanization level of these regions will be greatly improved. The urbanization level of the rest states and municipalities is only about $20 \%$. They're in the starting phase of urbanization. Compared with other states and municipalities, the urbanization level of Zhaotong and Nujiang ranks bottom in the province and is still in the backward phase with a big gap. The urbanization rate is an important sign of local economic and social development. The urbanization development level is often associated with the pace of economic development, and the low level of urbanization development also reflects that Yunnan is still one of the relatively underdeveloped provinces in social and economic development. The uneven development of urbanization reflects the uneven socioeconomic development in different regions of Yunnan. Generally speaking, Yunnan is in the accelerating period of urbanization, but the urbanization development is extremely uneven. Meanwhile, Yunnan faces many complex problems, including rich surplus labor force, hard cultivated land protection, stressful ecological protection, and weak urban infrastructure. Judging from urban registered unemployment rate index, the uneven 
development of urbanization has close connection with the level of economic development. With the lowest urban registered unemployment rate, Kunming is also the region with the highest level of economic development. While the regions with the highest urban registered unemployment rate, such as Nujiang and Zhaotong, are the most backward areas for the province's economic development. Judging from the index of secondary gross enrollment rate, the areas with higher levels of education are also the areas where the economy is relatively developed in the traditional sense. The secondary gross enrollment rate exceeds $80 \%$ in
Kunming, Yuxi and Qujing, belonging to the highest level of Yunnan. The level of socio-economic development in these three regions is the closest. The secondary gross enrollment rate of Zhaotong is just over $40 \%$, which is far behind the above regions. The advantage of the lack of human resources also further restricts the development of economic society in backward areas. In Yunnan, it can be seen that those underdeveloped areas face not only the urgent task of economic development, but also more prominent social development tasks.

\begin{tabular}{|c|c|c|c|c|c|c|}
\hline $\begin{array}{c}\text { Environment } \\
\text { Index }\end{array}$ & $\begin{array}{c}\text { Forest } \\
\text { Coverage } \\
(\%)\end{array}$ & $\begin{array}{c}\text { Industrial Solid } \\
\text { Waste Disposal } \\
\text { Rate (\%) }\end{array}$ & $\begin{array}{c}\text { Disposal } \\
\text { Rate of } \\
\text { Urban } \\
\text { Sewage (\%) }\end{array}$ & $\begin{array}{c}\text { Penetration of } \\
\text { Hygienic } \\
\text { Lavatories in } \\
\text { Rural Area (\%) }\end{array}$ & $\begin{array}{c}\text { Average } \\
\text { Park Area (m2) }\end{array}$ & $\begin{array}{c}\text { Virescence } \\
\text { Rate of Urban } \\
\text { Area (\%) }\end{array}$ \\
\hline Kunming & 46.1 & 50.6 & 96.9 & 71.6 & 10.3 & 42.4 \\
\hline Yuxi & 54.2 & 50.0 & 76.0 & 58.4 & 11.6 & 33.0 \\
\hline Qujing & 41.0 & 11.2 & 78.9 & 53.3 & 9.2 & 37.4 \\
\hline Baoshan & 61.9 & 23.0 & 35.8 & 56.6 & 9.3 & 29.9 \\
\hline Pu'er & 67.0 & 50.7 & 50.6 & 50.7 & 7.5 & 26.3 \\
\hline Lincang & 60.6 & 24.3 & 32.8 & 58.3 & 6.1 & 28.6 \\
\hline Lijiang & 66.2 & 85.0 & 79.6 & 50.9 & 18.2 & 33.1 \\
\hline Zhaotong & 32.6 & 51.3 & 36.4 & 50.7 & 3.4 & 17.2 \\
\hline Nujiang & 72.9 & 85.6 & 50.1 & 16.0 & 8.9 & 64.6 \\
\hline Xishuangbanna & 78.3 & 43.6 & 47.0 & 56.2 & 13.1 & 42.4 \\
\hline Dali & 58.2 & 21.5 & 71.6 & 49.3 & 5.9 & 26.4 \\
\hline Honghe & 44.8 & 17.2 & 71.4 & 56.1 & 9.3 & 32.7 \\
\hline Chuxiong & 62.5 & 11.3 & 73.2 & 70.4 & 11.5 & 32.6 \\
\hline Dehong & 67.1 & 6.9 & 63.0 & 57.7 & 9.8 & 26.5 \\
\hline Diqing & 73.9 & 26.2 & 81.0 & 54.3 & 5.6 & 10.0 \\
\hline Wenshan & 47.8 & 62.3 & 41.6 & 53.2 & 6.4 & 17.3 \\
\hline Yunnan & 52.9 & 46.6 & 79.7 & 55.1 & 9.1 & 33.1 \\
\hline
\end{tabular}

Table3: Environment condition

Data source: Yunnan Bureau of Statistics

\subsection{The Differences of Environment Condition}

Table three is the main indicators of environmental condition in the states and municipalities of Yunnan province. In terms of several key indexes, there's a large difference in states and municipalities. The highest disposal rate of urban sewage has reached $96.9 \%$ in Kunming, and the lowest is just $32.8 \%$ in Pu'er. The highest penetration of hygienic lavatories in rural area has approached $71.6 \%$ in Kunming, and the lowest is just $16.0 \%$. According to the numerical values of diversity indexes, the following will be the corresponding assignment.
One class of index, such as per capita GDP, and secondary gross enrollment rate, is positive assignment. These indicators are from high to low, and the higher numerical value gets the higher score. The score is arranged from the highest sixteen to the lowest one, and the same numerical value gets the same score. Another class of index, such as the income ratio between country and city, and urban registered unemployment rate, is negative assignment. The indicators are from low to high, and the higher numerical value gets the lower score. The score is arranged from the highest sixteen to the lowest one, and the same numerical value gets the same score. 


\begin{tabular}{|c|c|c|c|c|c|c|}
\hline $\begin{array}{c}\text { Economic } \\
\text { Development } \\
\text { Index }\end{array}$ & $\begin{array}{c}\text { Per Capita } \\
\text { GDP (yuan) }\end{array}$ & $\begin{array}{l}\text { Per Capita } \\
\text { Financial } \\
\text { Revenue } \\
\text { (yuan) }\end{array}$ & $\begin{array}{l}\text { Proportion of } \\
\text { the Increased } \\
\text { Value of the } \\
\text { Tertiary } \\
\text { Industry to } \\
\text { GDP (\%) } \\
\end{array}$ & $\begin{array}{c}\text { Urban } \\
\text { Residents’ Per } \\
\text { Capita } \\
\text { Disposable } \\
\text { Income (yuan) }\end{array}$ & $\begin{array}{c}\text { Farmers } \\
\text { Net Income } \\
\text { Per Capita } \\
\text { (yuan) }\end{array}$ & $\begin{array}{c}\text { Income Ratio } \\
\text { between Urban } \\
\text { and Rural } \\
\text { Areas (rural } \\
\text { areas is 1) }\end{array}$ \\
\hline Kunming & 16 & 16 & 14 & 16 & 16 & 14 \\
\hline Yuxi & 15 & 15 & 1 & 15 & 15 & 15 \\
\hline Qujing & 13 & 8 & 2 & 14 & 13 & 9 \\
\hline Baoshan & 6 & 4 & 9 & 8 & 9 & 10 \\
\hline Pu'er & 4 & 9 & 6 & 5 & 8 & 12 \\
\hline Lincang & 2 & 3 & 3 & 3 & 7 & 13 \\
\hline Lijiang & 8 & 13 & 13 & 7 & 6 & 8 \\
\hline Zhaotong & 1 & 1 & 5 & 2 & 2 & 4 \\
\hline Nujiang & 5 & 5 & 15 & 1 & 1 & 1 \\
\hline Xishuangbanna & 11 & 10 & 12 & 4 & 14 & 16 \\
\hline Dali & 9 & 6 & 8 & 11 & 12 & 6 \\
\hline Honghe & 10 & 12 & 4 & 10 & 11 & 11 \\
\hline Chuxiong & 12 & 7 & 7 & 12 & 10 & 5 \\
\hline Dehong & 7 & 11 & 11 & 6 & 4 & 7 \\
\hline Diqing & 14 & 14 & 16 & 13 & 5 & 2 \\
\hline Wenshan & 3 & 2 & 10 & 9 & 3 & 3 \\
\hline
\end{tabular}

Table 4 Scores for economic development

\begin{tabular}{|c|c|c|c|c|c|c|}
\hline $\begin{array}{l}\text { Social } \\
\text { Development } \\
\text { Index }\end{array}$ & $\begin{array}{c}\text { Urbanization } \\
\text { Rate (\%) }\end{array}$ & $\begin{array}{c}\text { Urban } \\
\text { Registered } \\
\text { Unemployment } \\
\text { Rate (\%) }\end{array}$ & $\begin{array}{l}\text { Secondary } \\
\text { Gross } \\
\text { Enrollment } \\
\text { Rate (\%) }\end{array}$ & $\begin{array}{c}\text { New Rural Medical } \\
\text { Cooperative Care } \\
\text { Participation Rate } \\
\text { (\%) }\end{array}$ & $\begin{array}{l}\text { Television } \\
\text { Coverage } \\
\text { (\%) }\end{array}$ & $\begin{array}{c}\text { Radio } \\
\text { Coverage (\%) }\end{array}$ \\
\hline Kunming & 16 & 16 & 16 & 9 & 15 & 16 \\
\hline Yuxi & 15 & 13 & 14 & 2 & 13 & 14 \\
\hline Qujing & 13 & 14 & 15 & 8 & 7 & 11 \\
\hline Baoshan & 6 & 8 & 11 & 6 & 4 & 7 \\
\hline Pu'er & 7 & 3 & 7 & 2 & 12 & 10 \\
\hline Lincang & 8 & 6 & 6 & 11 & 8 & 6 \\
\hline Lijiang & 4 & 11 & 10 & 12 & 5 & 2 \\
\hline Zhaotong & 1 & 1 & 1 & 4 & 3 & 3 \\
\hline Nujiang & 2 & 2 & 9 & 13 & 1 & 1 \\
\hline Xishuangbanna & 15 & 15 & 5 & 15 & 16 & 15 \\
\hline Dali & 11 & 4 & 13 & 5 & 14 & 8 \\
\hline Honghe & 12 & 10 & 8 & 7 & 10 & 9 \\
\hline Chuxiong & 9 & 12 & 12 & 9 & 11 & 13 \\
\hline Dehong & 10 & 5 & 2 & 16 & 2 & 4 \\
\hline Diqing & 3 & 7 & 4 & 14 & 9 & 12 \\
\hline Wenshan & 5 & 9 & 3 & 1 & 6 & 5 \\
\hline
\end{tabular}

Table 5 Scores for social development 


\begin{tabular}{|c|c|c|c|c|c|c|}
\hline $\begin{array}{l}\text { Environmental } \\
\text { Index }\end{array}$ & $\begin{array}{c}\text { Forest } \\
\text { Coverage (\%) }\end{array}$ & $\begin{array}{c}\text { Industrial Solid } \\
\text { Waste Disposal } \\
\text { Rate (\%) }\end{array}$ & $\begin{array}{l}\text { Disposal } \\
\text { Rate of } \\
\text { Urban } \\
\text { Sewage } \\
\text { (\%) }\end{array}$ & $\begin{array}{c}\text { Penetration of } \\
\text { Hygienic } \\
\text { Lavatories in Rural } \\
\text { Area (\%) }\end{array}$ & $\begin{array}{l}\text { Average } \\
\text { Park Area } \\
\text { (m2) }\end{array}$ & $\begin{array}{c}\text { Virescence } \\
\text { Rate of Urban } \\
\text { Area (\%) }\end{array}$ \\
\hline Kunming & 4 & 11 & 16 & 16 & 12 & 15 \\
\hline Yuxi & 6 & 10 & 12 & 14 & 14 & 12 \\
\hline Qujing & 2 & 2 & 13 & 7 & 8 & 13 \\
\hline Baoshan & 9 & 6 & 2 & 11 & 10 & 8 \\
\hline Pu'er & 12 & 12 & 7 & 4 & 6 & 5 \\
\hline Lincang & 8 & 7 & 1 & 13 & 4 & 7 \\
\hline Lijiang & 11 & 15 & 14 & 5 & 16 & 11 \\
\hline Zhaotong & 1 & 13 & 3 & 4 & 1 & 2 \\
\hline Nujiang & 14 & 16 & 6 & 1 & 7 & 16 \\
\hline Xishuangbanna & 16 & 9 & 5 & 10 & 15 & 15 \\
\hline Dali & 7 & 5 & 10 & 2 & 2 & 4 \\
\hline Honghe & 3 & 4 & 9 & 9 & 10 & 10 \\
\hline Chuxiong & 10 & 3 & 11 & 15 & 13 & 9 \\
\hline Dehong & 13 & 1 & 8 & 12 & 11 & 6 \\
\hline Diqing & 15 & 8 & 15 & 8 & 3 & 1 \\
\hline Wenshan & 5 & 14 & 4 & 6 & 5 & 3 \\
\hline
\end{tabular}

Table 6 Scores for environment condition

\begin{tabular}{|c|c|c|}
\hline & Comprehensive Score & Overall Ranking \\
\hline Kunming & 254 & 1 \\
\hline Xishuangbanna & 218 & 2 \\
\hline Yuxi & 215 & 3 \\
\hline Chuxiong & 180 & 4 \\
\hline Qujing & 172 & 5 \\
\hline Lijiang & 171 & 6 \\
\hline Diqing & 163 & 7 \\
\hline Honghe & 159 & 8 \\
\hline Dali & 137 & 9 \\
\hline Dehong & 136 & 10 \\
\hline Baoshan & 134 & 11 \\
\hline Pu'er & 131 & 12 \\
\hline Lincang & 116 & 13 \\
\hline Nujiang & 116 & 14 \\
\hline Wenshan & 96 & 15 \\
\hline Zhaotong & 52 & 16 \\
\hline
\end{tabular}

Table 7 Comprehensive score and overall ranking 
Table four to six are the corresponding assignment of diversity indexes. Table seven is obtained by the sum of integrated values and the rank circumstance. According to the score, the regions can be approximately divided into three categories. The first category is the regions getting the score above170, belonging to the regions with a higher level of social development; The second category is the regions getting the score between 120 and 170 , belonging to the regions with a medium level of social development; The third category is the regions getting the score below 120 , belonging to the regions with a lower level of social development. It can be seen that the first regions expect Xishuangbanna and Lijiang the remaining four belong to Yunnan midland with the highest level of economic and social development in the traditional sense. It is also noteworthy that Xishuangbanna is not the most developed region of Yunnan, but it ranks forward in the indexes of social development and environmental condition. The overall ranking of Xishuangbanna is the second in Yunnan, even getting ahead of the traditional developed regions--Yuxi and Qujing. Similarly, Diqing, the underdeveloped region, ranks the seventh getting ahead of the more developed regions such as Dali and Honghe. It is mainly due to its relevant indicators of social development and environmental condition getteing higher scores. That reflects that economic development level does not necessarily determines to social development level to a certain extent. On the contrary, the industrial development may adversely affect the environmental condition, and further affect the overall social development. Therefore, it is necessary to establish the development strategy of environmental priorities and ensure the coordinative development of economy, society and environment. Only in terms of scores, there is a big gap in the level of social development between the first regions and the third regions. Zhaotong, the traditional underdeveloped region of Yunnan, ranks last in the comprehensive score. Kunming ranks the first, and there is a score difference of 200 between the two. Although the economic development level does not necessarily determines to social development level, economic development objectively has an important affection on social development to a certain extent. Economic and social development is the result of mutual constraint and mutual influence. Especially in aspects of education and medical service, social development can affect the development of human resources and further affect economic development for an area. The situation of regional economic development can have direct affection on regional employment and relevant investment in public service.
Therefore, it is necessary for those backward areas to speed up the development, at the same time to notice the coordination of economic and social development.

\section{Conclusion}

Overall, there are obvious differences in the situation of social development of our province. In the process of accelerating economic and social development and promoting the equalization of essential public services, people should focus on the differences in regional development; strengthen the harmony development with special focus and aims and enhance the balance between economic development and social development.

\section{References}

[1] Statistics Bureau of Yunnan Province: Yunnan Statistical Yearbook 2012, 2012. 8.

[2] Statistics Bureau of the States and Municipalities in Yunnan Province: National Economic and Social Statistical Bulletin of the States and Municipalities 2011, 2012.

[3] The Government of States and Municipalities in Yunnan Province: The Government Work Report of States and Municipalities 2011, 2012. 